\title{
ROBOT PENGETIK UNTUK ALAT BANTU PENGOPERASIAN KOMPUTER BAGI PENYANDANG CACAT
}

\author{
Syamsiar Kautsar ${ }^{1}$, Bety Etikasari ${ }^{2}$, Beni Widiawan ${ }^{3}$ dan K. Agustianto ${ }^{4}$ \\ 1,2,3,4 Jurusan Teknologi Informasi, Politeknik Negeri Jember \\ ${ }^{1}$ syamsiar_kautsar@polije.ac.id, ${ }^{2}$ bety.etikasari@gmail.com, ${ }^{3}$ beni@polije.ac.id, ${ }^{4}$ agustianto.khafid@gmail.com
}

\begin{abstract}
Abstrak
Pada tahun 2005, UNICEF memperkirakan jumlah anak-anak penyandang cacat di bawah usia 18 tahun dari 150 juta anak. Indonesia mempunyai 11 juta pekerja penyandang cacat. Jumlah ini kurang dari 50\% jumlah penderita cacat (data tahun 2010). Berbagai upaya telah dilakukan untuk membantu penyandang cacat agar dapat bekerja secara normal. Ada banyak penelitian tentang kaki palsu, tangan buatan, dan kursi roda bermotor. Dalam penelitian ini akan membangun sebuah robot pengetik. Ini dirancang untuk penyandang cacat fisik. Fungsi robot ini dapat membantu orang cacat untuk mengoperasikan computer secara normal. Robot pengetik terdiri dari 2 robot lengan. Setiap lengan mempunyai 4 derajat kebebasan (DOF). Sensor kompas dengan kompensasi kemiringan dipasang pada kaki pengguna. Ini digunakan untuk mengukur pergerakan kaki pengguna. Keyboard USB ukuran mini digunakan sebagai objek kerja robot. Sebuah rule-based dibuat untuk mengkonversi gerakan kaki pengguna menjadi gerakan robot pengetik. Pembuatan rule-based mempunyai tingkat keberhasilan $100 \%$ (untuk keseluruhan akses tombol) dan kesalahan posisi maksimum $3 \mathrm{~mm}$.
\end{abstract}

Kata kunci : lengan robot, disabilitas, rule-based

\section{Pendahuluan}

Manusia terlahir dengan dua kondisi, pertama dalam kondisi normal dan kedua dalam kondisi cacat. Pada kondisi normal, berbagai aktifitas dapat dilakukan secara normal karena semua sistem dapat menjalankan tugas sesuai dengan fungsinya masingmasing. Namun berbeda dengan kondisi yang kedua, karena terdapat beberapa fungsi tubuh yang terganggu secara psikis maupun secara fisik pada tubuh seseorang tersebut, sehingga beberapa aktifitas tidak dapat dikerjakan secara mandiri (membutuhkan bantuan manusia lain atau alat). Pada kondisi ini seseorang tersebut dapat dikategorikan sebagai penyandang cacat. Sekarang, istilah penyandang cacat telah digantikan dengan penyandang disabilitas yang merupakan kata serapan dari bahasa Inggris yaitu disability yang memiliki arti cacat atau ketidakmampuan.

Berbagai upaya dilakukan agar penyandang disabilitas mendapatkan kesetaraan hak dengan sesorang yang memiliki kondisi normal. Hal tersebut sesuai dengan Peraturan Pemerintah Republik Indonesia Nomor 43 Tahun 1998 pada Bab II Pasal 6 yang membahas tentang kesamaan kesempatan bagi penyandang disabilitas diarahkan untuk mewujudkan kesamaan kedudukan, hak, kewajiban dan peran penyandang disabilitas, agar dapat berperan dan berintegrasi secara total sesuai dengan kemampuannya dalam segala aspek kehidupan dan penghidupan. Namun pada penerapan di kehidupan sehari-hari, masih banyak dijumpai penyandang disabilitas yang merasa kesulitan bahkan tidak bisa melakukan aktifitas tertentu terutama aktifitas yang berhubungan dengan kesempatan untuk bekerja[1]. Beberapa teknologi juga telah dikembangkan untuk membantu aktifitas para penyandang disabilitas, seperti kursi roda yang dikontrol dengan gerakan [2][3], powered exoskeleton [4][5], asisten robot [6], lengan buatan [7], dan lain sebagaianya. Hal ini dibuat untuk membantu penyandang disabilitas agar dapat bekerja secara normal. Pada penelitian ini, dibuat sepasang lengan robot yang memiliki masingmasing 4 derajat kebebasan yang dapat menggantikan fungsi jari manusia untuk melakukan pengetikan di keyboard standart. Ini ditujukan untuk pasien penyandang disabilitas pada tangan, yang kedua kakinya masih berfungsi. Robot pengetik menggunakan keyboard standar, sehingga pengguna dapat menggunakannya pada berbagai perangkat komputer. Untuk bisa menggerakkan lengan robot, sensor kompas CMPS11 dipasang pada kaki pengguna. Sensor ini digunakan untuk membaca orientasi pergerakan kaki pengguna. Metode rulebased diimplementasikan pada kontroler untuk mengubah orientasi gerakan kaki menjadi sudut kerja dari motor servo. Nantinya, pengguna cukup menghubungkan alat ke port USB komputer, tanpa perlu menginstal driver tambahan.

\section{Desain dan Perencanaan}

\subsection{Invers Kinematik}


Kinematika dapat didefenisikan sebagai studi pergerakan robot (motion) tanpa memperhatikan gaya (force) ataupun faktor lain yang mempengaruhi pergerakan robot tersebut. Pada sebuah analisis kinematik, posisi, kecepatan dan akselerasi dan seluruh link dihitung tanpa memperhatikan gaya yang menyebabkan pergerakan tersebut. Kinematika robot secara umum terbagi menjadi dua, yaitu:

\section{a. Kinematika Maju (Forward)}

Kinematika maju adalah analisis kinematik untuk mendapatkan kordinat posisi $(\mathrm{x}, \mathrm{y}, \mathrm{z})$ jika diketahui nilai sudut dari setiap sendi. Sebagai contoh, jika mempunyai robot n-DOF (Degree of freedom) dan diketahui sudut dari tiap sendi maka dapat digunakan analisis kinematik maju untuk mendapatkan kordinat posisi dari robot. Untuk perhitungannya sesuai dengan persamaan berikut:

$$
\begin{aligned}
& x=I 1 \cos \theta 1+I 2 \cos (\theta 1+\theta 2) \ldots(1) \\
& y=I 1 \sin \theta 1+I 2 \sin (\theta 1+\theta 2)
\end{aligned}
$$

\section{b. Kinematika Mundur (Invers)}

Kinematika inversi adalah analisis kinematik untuk mendapatkan besar sudut dari masing-masing sendi jika mempunyai data kordinat posisi $(\mathrm{x}, \mathrm{y}, \mathrm{z})$ [12]. Pemodelan invers kinematik dapat dilakukan melalui pendekatan matematis ataupun deterministik. Penggunaan metode deterministik diperlukan data masukan dan keluaran untuk proses pemodelan

\subsection{Rule-Based}

Dalam ilmu komputer, rule-based system digunakan sebagai cara untuk menyimpan dan memanipulasi pengetahuan untuk menafsirkan informasi dengan cara yang bermanfaat. Rule-based system dapat diterapkan pada sistem yang melibatkan seperangkat aturan buatan manusia. Contoh klasik dari sistem berbasis aturan adalah sistem pakar yang menggunakan aturan untuk membuat diagnosa atau pilihan. Misalnya, sistem pakar untuk membantu dokter memilih diagnosis yang benar berdasarkan gejala-gejala penyakit yang muncul. Sistem berbasis aturan dapat digunakan untuk melakukan analisis untuk mengkompilasi program komputer, atau menafsirkan pemrosesan bahasa alami. Pemrograman berbasis aturan mencoba untuk mendapatkan instruksi eksekusi dari seperangkat data dan aturan awal. Ini adalah metode yang dapat digunakan secara tidak langsung selain bahasa pemrograman imperatif, yang berisi daftar langkah-langkah eksekusi secara berurutan.

\subsection{Struktur Robot Pengetik}

Struktur dari robot pengetik ditunjukkan pada Gambar 1. Robot pengetik terdiri atas 2 lengan. Setiap lengan memiliki 4 motor penggerak. 3 motor digunakan untuk mengubah posisi kerja lengan, satu motor lainnya digunakan untuk menekan tombol pada keyboard. Servo digital Dynamixel AX-12A digunakan sebagai motor penggerak pada robot. Servo dynamixel AX-12A memiliki resolusi kerja $0,222 \mathrm{o} /$ bit. Setiap motor memiliki nomor ID tertentu yang ditunjukkan pada gambar 1. Pada penelitian ini, lengan kanan digunakan untuk mengakses semua tombol pada keyboard. Lengan kiri hanya digunakan untuk menekan tombol Shift kiri.

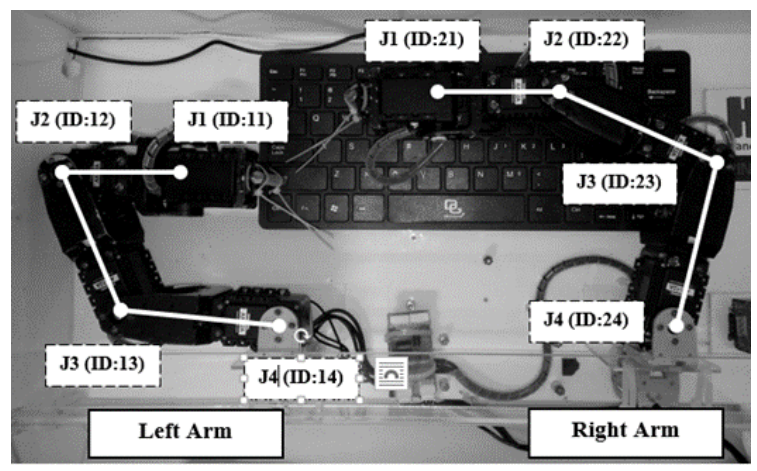

Gambar 1. Struktur lengan robot pengetik

Semua motor terhubung ke kontroler AVR ATMega2560 secara paralel. Karena komunikasi data servo Dynamixel menggunakan komunikasi halfduplex asynchronous serial, diperlukan tri-state buffer IC 74LS241. IC tersebut digunakan sebagai penghubung komunikasi UART antara kontroler ATMega2560 dengan servo dynamixel. Kontroler juga digunakan untuk membaca data sensor CMPS11. CMPS11 merupakan sensor kompas yang dilengkapi dengan kompensasi kemiringan. Sensor CMPS11 terdiri dari 3axis magnetometer, 3axis acceleromoter dan 3 axis gyro. Dalam penelitian ini, data pitch dan roll dari sensor kompas digunakan sebagai data masukan pada sistem. Diagram blok sistem dari robot pengetik ditunjukkan pada Gambar 2. Terdapat 2 buah limit switch yang dipasang di dekat kaki pengguna. Switch pertama digunakan untuk menekan tombol tanpa Shift, switch kedua digunakan untuk menekan tombol dengan Shift (mengakses huruf besar atau karakter unik pada keyboard).

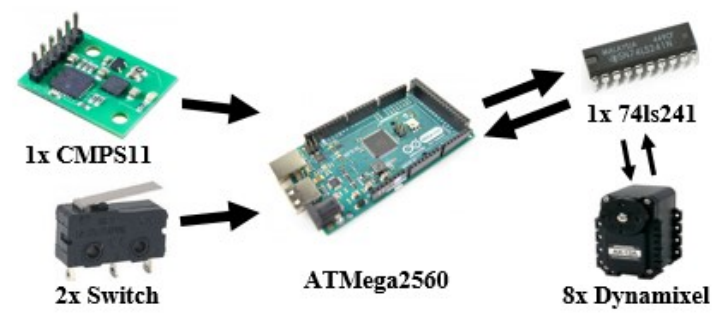

Gambar 2. Diagram blok sistem robot pengetik

\subsection{Pemetaan Keyboard}

Keyboard yang digunakan adalah keyboard mini dengan merk dagang K-1000. Keyboard tersebut tersusun atas 78 tombol. Untuk memudahkan konversi data, keyboard dipetakan dalam koordinat 
Cartesian. Keyboard dibagi menjadi 4 bagian, yaitu bagian I, II, III, dan IV. Bagian I memiliki nilai X dan $\mathrm{Y}$ positif. Bagian II memiliki nilai $\mathrm{X}$ negatif dan nilai $\mathrm{Y}$ positif. Bagian III memiliki nilai X dan $\mathrm{Y}$ negatif. Bagian IV memiliki nilai X negatif dan nilai Y positif. Sebagai contoh: koordinat "U" adalah $(1,1)$, koordinat " $G$ " adalah koordinat $(-1,-2)$, dan " 5 " adalah $(2,2)$. Setiap bagian terdiri dari 21 tombol. Ada beberapa tombol yang memiliki lebih dari satu koordinat, yaitu tombol Enter, shift kiri, shift kanan, dan spasi. Hal ini bertujuan untuk memudahakan perhitungan. Gambar 3 merupakan ilustrasi pemetaan area pada keyboard secara visual.
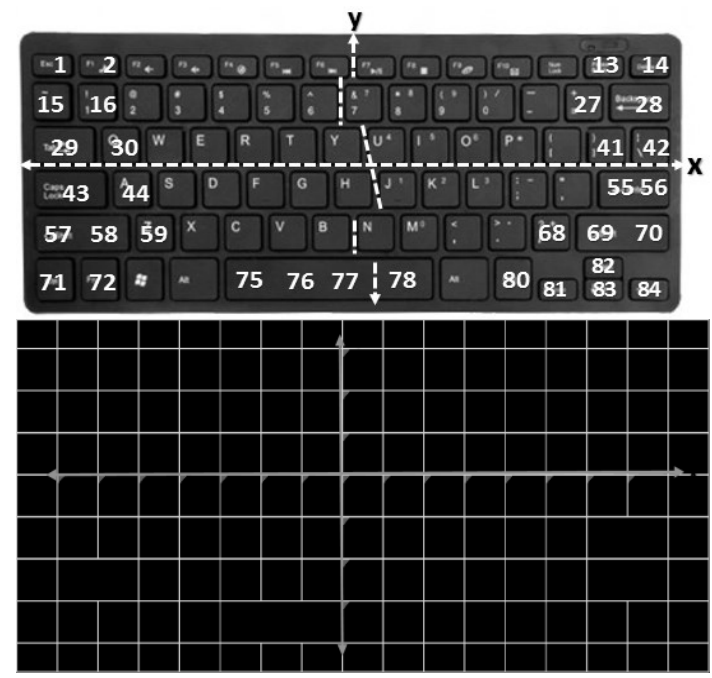

Selanjutnya, dilakukan pengambilan data sudut kerja servo berdasarkan data posisi tombol pada keyboard. Lengan robot bagian kanan diposisikan secara manual pada setiap tombol pada keyboard. Nilai sudut kerja servo selanjutnya di simpan sesuai dengan data pada tabel 1 . Sudut kerja servo $0^{\circ}-150^{\circ}$ direpresentasikan dalam bilangan 10 bit (0-1023).

Tabel 1. Data sudut kerja lengan robot berdasarkan posisi tombol

\begin{tabular}{|c|c|c|c|c|c|c|}
\hline In & Key & $\mathbf{X}$ & $\mathbf{Y}$ & Servo22 & Servo23 & Servo24 \\
\hline 1 & ESC & 7 & 3 & 413 & 404 & 442 \\
\hline 2 & $\mathrm{~F} 1$ & 6 & 3 & 402 & 359 & 483 \\
\hline 3 & $\mathrm{~F} 2$ & 5 & 3 & 400 & 318 & 525 \\
\hline 4 & F3 & 4 & 3 & 386 & 297 & 558 \\
\hline 5 & $\mathrm{~F} 4$ & 3 & 3 & 375 & 277 & 589 \\
\hline 6 & F5 & 2 & 3 & 357 & 267 & 619 \\
\hline 7 & F6 & 1 & 3 & 359 & 238 & 657 \\
\hline 8 & F7 & 1 & 3 & 351 & 223 & 691 \\
\hline 75 & $\begin{array}{l}\text { SPA } \\
\text { CE } \\
\end{array}$ & $\begin{array}{l}- \\
3\end{array}$ & 3 & 266 & 269 & 560 \\
\hline 76 & $\begin{array}{l}\text { SPA } \\
\text { CE }\end{array}$ & $\overline{2}$ & $\begin{array}{l} \\
3\end{array}$ & 242 & 256 & 590 \\
\hline
\end{tabular}

\begin{tabular}{|c|c|c|c|c|c|c|}
\hline 77 & $\begin{array}{l}\text { SPA } \\
\text { CE }\end{array}$ & $\overline{1}$ & - & 212 & 239 & 636 \\
\hline 78 & $\begin{array}{l}\text { SPA } \\
\text { CE }\end{array}$ & 1 & - & 222 & 197 & 699 \\
\hline 79 & $\begin{array}{l}\text { ALT } \\
\text { KA } \\
\text { NA } \\
\text { N }\end{array}$ & 2 & - & 210 & 181 & 759 \\
\hline 80 & $\begin{array}{l}\text { CTR } \\
\text { L } \\
\text { KA } \\
\text { NA } \\
\mathrm{N} \\
\end{array}$ & 3 & - & 176 & 196 & 783 \\
\hline 81 & $\begin{array}{l}\text { PG } \\
\text { UP }\end{array}$ & 4 & - & 117 & 259 & 806 \\
\hline 82 & $\begin{array}{l}\mathrm{HO} \\
\mathrm{ME}\end{array}$ & 5 & 3 & 115 & 247 & 760 \\
\hline 83 & $\begin{array}{l}\text { PG } \\
\text { DN }\end{array}$ & 6 & 3 & 84 & 276 & 783 \\
\hline 84 & $\begin{array}{l}\text { EN } \\
\text { D } \\
\end{array}$ & 7 & 3 & 78 & 290 & 819 \\
\hline
\end{tabular}

\subsection{Pembuatan Rule-Based}

Sudut pitch dan roll yang dihasilkan sensor kompas CMPS11 memiliki rentang nilai -90o s/d 90o. Diperlukan proses penyekalaan untuk mengubah data sudut pitch dan roll menjadi data koordinat cartesius. Penyekalaan data roll menggunakan persamaan 3, sedangkan penyekalaan data pitch menggunakan persamaan 4. Selanjutnya nilai X, Y yang dihasilkan diproses pada rule-based untuk memperoleh sudut kerja yang sesuai dengan data pada tabel 1. Misalkan, nilai sudut roll $=43 \mathrm{o}$ dan nilai sudut pitch $=22 \mathrm{o}$, maka nilai $X=4$ dan nilai $Y=2$. Berdasarkan data yang disimpan pada kontroler, maka nilai koordinat $(4,2)$ memiliki nilai indeks $=25$. Selanjutnya, kontroler akan mengirimkan nilai sudut pada servo22[25] = 330 , servo $23[25]=173$, servo $24[25]=795$ sehingga lengan robot bagian kanan akan mengarah pada tombol " 0 ".

$$
\begin{gathered}
f(r)=\left\{\begin{array}{c}
x_{\text {norm }}=-7, r<-70 \\
x_{\text {norm }}=7, r>70 \\
x_{\text {norm }}=\frac{r}{10}, \quad-70 \leq r \leq 70
\end{array}\right. \\
f(s)=\left\{\begin{array}{c}
y_{\text {norm }}=-4, r<-40 \\
y_{\text {norm }}=4, r>40 \\
y_{\text {norm }}=\frac{s}{10},-40 \leq r \leq 40
\end{array}\right.
\end{gathered}
$$

\section{Pengujian Sistem}

Sistem ini diuji dengan mengarahkan lengan robot pada semua tombol pada keyboard. Berdasarkan hasil uji coba, robot berhasil mengakses semua tombol pada keyboard. Gambar 9 mewakili posisi penekanan tombol selama pengujian. Meskipun robot dapat mengakses semua tombol dengan benar, namun ada perbedaan posisi penekanan tombol dengan posisi pada saat penyimpanan data. Pada saat penyimpanan data, posisi penekanan tombol diarahkan ke bagian tengah 


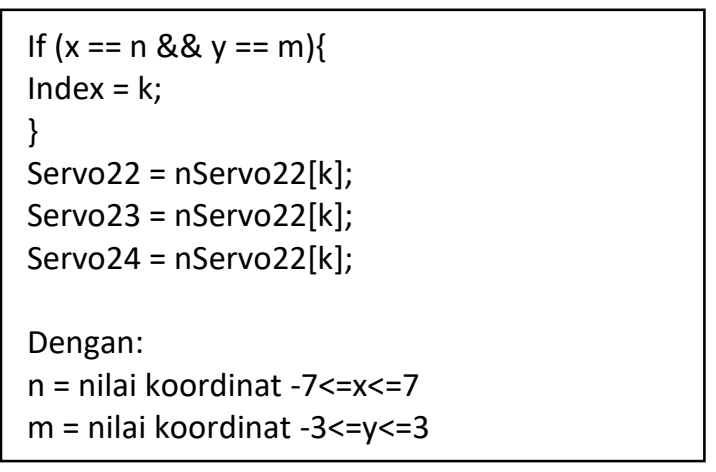

tombol. Kesalahan terbesar adalah sekitar $3 \mathrm{~mm}$ dari bagian tengah tombol. Gambar 10 adalah foto pada saat pengujian lengan robot.

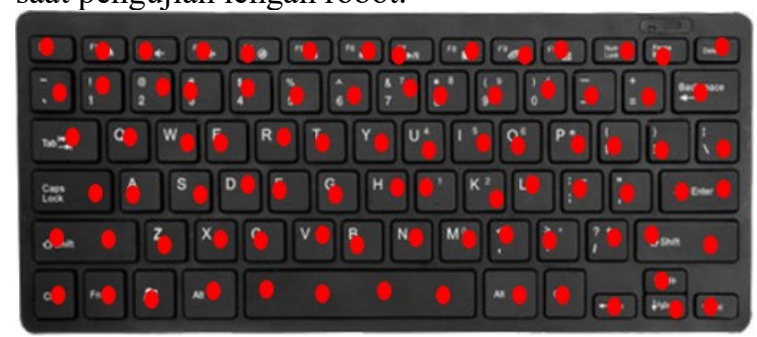

(a)
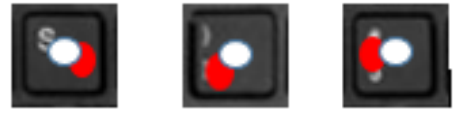

(b)

Gambar 9. a) Posisi penekanan tombol, b) Penyimpangan posisi penekanan tombol

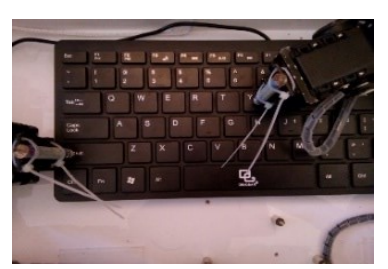

(a)

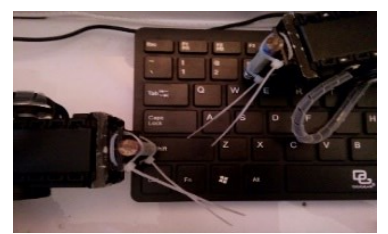

(c)

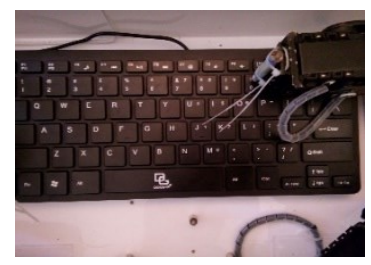

(b)

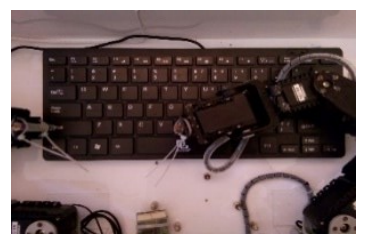

(d)
Gambar 10. Posisi Robot Pengetik pada a) roll $=-120$, pitch $=-50, b)$ roll $=32 \mathrm{o}$, pitch $=-28 \mathrm{o}, \mathrm{c}$ ) roll $=-460$, pitch $=-24 \mathrm{o}, \mathrm{d}$ ) roll $=-4 \mathrm{o}$, pitch $=23 \mathrm{o}$

\section{Kesimpulan}

Berdasarkan pengujian yang telah dilakukan, rule-based system yang diimplementasikan pada robot dapat digunakan untuk mengakses semua tombol pada keyboard. Robot tersebut dapat digunakan untuk membantu penyandang disabilitas pada tangan untuk mengoperasikan komputer. Pengguna cukup memasangkan sensor pada kaki untuk menggerakkan lengan robot pengetik. Perangkat ini merupakan perangkat plug and play yang bisa digunakan untuk berbagai komputer. Sistem yang dibuat juga telah diuji pada perangkat komputer mini Raspberry dengan sukses. Penyimpangan posisi penekanan tombol dapat diakibatkan oleh nilai toleransi kerja servo dynamixel. Meski terdapat kesalahan posisi, hal tersebut tidak mengganggu performa robot. Untuk penelitian selanjutnya, akan digunakan dua lengan robot secara aktif untuk mempercepat proses pengetikan.

\section{Daftar Pustaka:}

Ira Retnaningsih, Rahmat Hidayat. 2012. Representasi Sosial tentang Disabilitas Intelektual pada Kelompok Teman Sebaya. Jurnal Psikologi Volume 39, No 1, JUNI 2012: $13-24$.

R.K. Megalingam, et al, "Gesture controlled wheel chair using IR-LED TSOP pairs along with collision avoidance", International Conference on Robotics and Automation for Humanitarian Applications (RAHA), Dec 2016.

M. Challagundla, K.Y. Reddy, N.H. Vardhan, "Automatic motion control of powered wheel chair by the movements of eye blink", International Conference on Advanced Communication Control and Computing Technologies (ICACCCT), May 2014

Di Ao, Rong Song, Jinwu Gao, "Movement Performance of Human-Robot Cooperation Control Based on EMG-Driven Hill-Type and Proportional Models for an Ankle Power-Assist Exoskeleton Robot", IEEE Transactions on Neural Systems and Rehabilitation Engineering, Vol. 25, Issue: 8, pp. 1125-1134, 2017.

Jian Huang, et al, "Control of Upper-Limb PowerAssist Exoskeleton Using a Human-Robot Interface Based on Motion Intention Recognition," IEEE Transactions on Automation Science and Engineering, vol. 12, pp. 1257-1270, 2015.

Weiguang Li, et al., "Development of a 3 freedom ankle robot to assist the rehabilitation training", IEEE International Conference on Information and Automation (ICIA), August 2016.

S. Kautsar, P.A. Darwito, S. T. Sarena, "Kinect Depth Image Processing for Hand Motion Recognition using Neural Network Backpropagation," 1st IPTEK Journal of Proceedings Series, 2015.

W.K. Dewanto, et al, (2017), "A control scheme for typist robot using Artificial Neural Network", International Conference on Sustainable Information Engineering and Technology (SIET),2017,DOI: 10.1109/SIET.2017.8304167

Artemiadis, Panagiotis K. dan Kyriakopoulos, Kostas J. (2010b), "EMG-Based Control of a Robot 
Arm Using Low-Dimensional Embeddings", IEEE Transactions on Robotics, Vol. 26, No. 2, hal. 393-398

Artemiadis, Panagiotis K. dan Kyriakopoulos, Kostas J. (2011a), "A Switching Regime Model for the EMG-Based Control of a Robot Arm", IEEE Transactions on Systems, Man, and Cybernetics - Part B: Cybernetics, Vol. 41, No. 1, hal. 53-63

Kofman, Jonathan, $\mathrm{Wu}$, Xianghai, Luu, T.J., dan Verma, Siddharth (2005), "Teleoperation of a Robot Manipulator using a Vision-Based Human-Robot Interface", IEEE Transactions on Industrial Electronics, Vol. 52, No. 5, hal. 12061219

Rafiuddin Syam. 2015. Seri Buku Ajar Robotika: Kinematika dan Dinamika Robot Lengan. Makassar: Fakultas Teknik Universitas Hasanuddin. 